\title{
Pembuatan Media Informasi Songket Lombok Produksi UD. Undur Pasang
}

${ }^{1}$ Sri Sukarni, ${ }^{2}$ Pyo Apriliana Munawaroh, ${ }^{3}$ Lalu Aswandi Mahroni, ${ }^{4}$ Lalu Purnama Zulkarnaen,

${ }^{5}$ Rohmayadi

Universitas Pendidikan Mandalika, Jl. Pemuda No. 59A, Mataram, Indonesia 83125

Email Korespondensi: srisukarni63@gmail.com

\begin{tabular}{|c|c|}
\hline Arti & stract \\
\hline $\begin{array}{l}\text { Article History } \\
\text { Received: } 2020-10-10 \\
\text { Revised: } 2020-10-22 \\
\text { Published: } 2020-10-30\end{array}$ & \multirow{2}{*}{$\begin{array}{l}\text { Making Information Media for Lombok Songket Produced by UD. Undur } \\
\text { Pasang. This community service aimed to make information media about } \\
\text { Songket and other products of UD. Undur Pasang. UD. Undur Pasang } \\
\text { produces and sells Lombok Songket located in Montong Are Blong Lauq of } \\
\text { Sukarara village. UD. Undur Pasang does not yet have information media so } \\
\text { that many people do not know its products. Therefore, it is necessary to make } \\
\text { product information media. Catalog is chosen as product information media } \\
\text { because it is not only easy and cheap but also communicative. The three } \\
\text { methods applied in this community service were preparation, implementation } \\
\text { and evaluation. First, team of community service made a concept based on } \\
\text { products of UD. Undur Pasang. Then, all products consisted of Songket, other } \\
\text { woven fabrics and accessories are photographed by camera from different } \\
\text { sides/angle to get interesting pictures. Finally, color image catalog that } \\
\text { contained products of UD. Undur Pasang was the result of the community } \\
\text { service. }\end{array}$} \\
\hline $\begin{array}{l}\text { Keywords } \\
\text { catalog, } \\
\text { information } \\
\text { product }\end{array}$ & \\
\hline Info & Abstrak \\
\hline $\begin{array}{l}\text { SejarahArtikel } \\
\text { Diterima: } 10-10-2020 \\
\text { Direvisi: } 22-10-2020 \\
\text { Dipublikasi: } 30-10-30\end{array}$ & \multirow{2}{*}{$\begin{array}{l}\text { Pengabdian Kepada Masyarakat ini bertujuan untuk membuat media informasi } \\
\text { tentang songket dan produk lainnya dari UD. Undur Pasang. UD. Undur } \\
\text { Pasang memproduksi dan menjual Songket Lombok beralamat di Dusun } \\
\text { Montong Are Blong Lauq Desa Sukarara. UD. Undur Pasang belum memiliki } \\
\text { media informasi produk sehingga masyarakat banyak yang belum mengenal } \\
\text { produknya. Oleh karena itu, perlu dibuat media informasi produk. Katalog } \\
\text { dipilih sebagai media informasi produk karena bukan hanya mudah dan murah } \\
\text { tetapi komunikatif. Ada tiga metode yang digunakan dalam Pengabdian } \\
\text { Kepada Masyarakat ini yaitu persiapan, pelaksanaan, dan evaluasi. Pertama } \\
\text { tim Pengabdian Kepada Masyarakat membuat konsep berdasarkan produk } \\
\text { UD. Undur Pasang. Kemudian seluruh produk yang terdiri dari Songket, kain } \\
\text { tenun lainnya dan aksesori difoto dari sisi yang berbedalangle sehingga } \\
\text { menghasilkan gambar yang menarik. Hasil dari Pengabdian Kepada } \\
\text { Masyarakat ini adalah katalog dengan gambar berwarna tentang produk UD. } \\
\text { Undur Pasang }\end{array}$} \\
\hline & \\
\hline
\end{tabular}

Sitasi: Sukarni S., Munawaroh A.P., Mahroni A.L., Zulkarnain P.L., \& Rohmayadi (2020) Pembuatan Media Informasi Songket Lombok Produksi UD. Undur Pasang. Sasambo: Jurnal Abdimas (Journal of Community Service). 2(3), 127-133 : DOI : 10.36312/sasambo.v2i3.291

PENDAHULUAN

UD. Undur Pasang adalah usaha dagang yang memproduksi dan menjual kain tenun Songket khas Lombok. Usaha ini dirintis sejak April 2007 dan beralamat di Dusun Montong Are Blong Lauq Desa Sukarara Kecamatan Jonggat Kabupaten Lombok Tengah. UD. Undur 
Pasang tidak hanya menjual kain Songket khas Lombok tetapi juga menjual pakaian adat Lombok dan aksesori.

Perkembangan pasar yang sangat dinamis, mengakibatkan banyak Usaha Dagang atau Perusahaan yang ingin terjun pada bidang usaha yang sama. Hal ini menyebabkan persaingan terjadi diantara usaha dagang tersebut untuk menarik perhatian dan memasarkan produk mereka kepada target market. Begitu banyaknya persaingan menyebabkan perusahaan berlomba-lomba untuk mempromosikan produknya agar dikenal oleh khalayak. Masyarakat mengenal produk atau brand melalui media promosi, oleh karena itu media informasi produk diperlukan oleh UD. Undur Pasang.

Media merupakan alat atau wahana yang digunakan sumber untuk menyampaikan pesannya kepada penerima (Mulyana, 2005). Media merupakan saluran, alat atau sarana penghubung, perantara dan pengantar. Media merupakan alat teknis yang digunakan untuk menyampaikan pesan, dengan kata lain media merupakan alat komunikasi. Dalam melakukan komunikasi, manusia sering mendapatkan pesan-pesan yang disampaikan secara non verbal antara lain melalui wajah, pandangan mata, gerak hingga pakaian (Ruben \& Stewart, 2013). Sementara kata komunikasi berarti menyampaikan suatu pesan dari komunikator (penyampai pesan) dan komunikan (penerima pesan) melalui suatu media dengan maksud tertentu. (Bungin, 2006). Media komunikasi merupakan perantara dalam penyampaian informasi dari komunikator kepada komunikan yang bertujuan untuk efisiensi penyebaran informasi atau pesan tersebut. Dengan kata lain kegiatan promosi merupakan kegiatan komunikasi.Media promosi merupakan salah satu solusi cara untuk memperkenalkan produk barang/jasa yang diproduksi oleh perusahaan melalui beragam jenis media promosi. Diantaranya adalah melalui website, sosial media, iklan media elektronik, iklan media cetak, poster, banner, brosur dan jenis promosi lainnya.

Promosi merupakan sarana paling ampuh untuk menarik dan mempertahankan konsumen (Rompis, Tumbuan, \& Sumarauw, 2017). Dengan adanya promosi maka konsumen akan mengetahui produk yang ditawarkan oleh perusahaan. Setelah konsumen mengenal produk yang ditawarkan maka mereka ingin memiliki atau membeli dan menggunakan produk tersebut. Dengan perkataan lain, promosi merupakan media komunikasi.

Katalog adalah sejenis brosur yang berisi rincian jenis produk yang dilengkapi dengan gambar-gambar (Kusrianto, 2007). Ukurannya bermacam-macam mulai sebesar saku sampai sebesar buku telepon, tergantung keperluan. Katalog merupakan sebuah media cetak yang bertujuan untuk menyebarkan informasi. Secara fisik bentuk katalog adalah cetakan yang terdiri dari beberapa halaman yang dijilid sehingga menyerupai buku. Media katalog berfungsi antara lain sebagai daftar atau koleksi sesuatu yang memiliki informasi tertentu.

Kesulitan calon pelanggan dapat teratasi apabila perusahaan melakukan promosi melalui katalog produk. Katalog promosi produk merupakan daftar informasi tentang produkproduk yang ditawarkan oleh perusahaan atau agen pemasaran (Kotler \& Amstrong, 2014). Tujuannya adalah untuk memberi cukup informasi tentang produk-produk tersebut sehingga memudahkan konsumen untuk memilih produk yang diinginkannya. Katalog didesain sedemikian rupa sehingga memenuhi syarat sebagai alat promosi yang efektif dan efisien. Hasanah (2015) halaman pertama katalog berisi tentang gambaran produsen, visi misi produsen, contact person, kualitas dan teknologi yang digunakan, gambar tempat produksi, sistem produksi dan tenaga kerja. Bagian terpenting dari katalog adalah informasi rinci mengenai produk atau jasa yang dijual. Deskripsi detail tentang item produk dan harga serta tidak kalah penting adalah informasi tentang kontak alamat, nomor telpon, website, email, dan informasi lainnya yang dianggap perlu.

Penelitian tentang pentingnya katalog telah dilaksanakan oleh Cahyadi \& Wijaya (2011). Penelitian ini mengambil obyek katalog produk Carrefour dan hasilnya produk yang diiklankan, desain iklan, pesan iklan, brand image, dan harga produk memiliki pengaruh 
yang signifikan terhadap minat beli kembali. Praswati (2016) menyimpulkan bahwa katalog menjawab pertanyaan pelanggan mengenai produk atau dengan perkataan lain dapat mewakili produk kerajinan bambu yang akan ditawarkan. Keterbatasan dari penelitian ini adalah hasil penerapan katalog sebagai media promosi kerajinan bambu belum dapat dilihat karena membutuhkan waktu yang cukup lama serta komitmen dari para pengrajin untuk aktif menawarkan produk melalui katalog yang telah disusun. Putra (2019) meneliti tentang Perancangan Katalog Wisata Kota Surabaya sebagai Media Informasi Massa. Penelitian ini menghasilkan katalog wisata Surabaya yang dikemas dalam media yang lebih menarik lagi dengan mengedepankan banyak gambar-gambar.

Berdasarkan penjelasan teori-teori di atas dapat disimpulkan bahwa katalog adalah jembatan informasi produk/koleksi suatu perusahaan secara rinci kepada konsumen. Untuk mempromosikan produk-produk UD. Undur Pasang secara efektif maka diperlukan pembuatan media informasi produk. Oleh sebab itu perlu dibuat media promosi produk songket UD. Undur Pasang. Media informasi diperlukan UD. Undur Pasang untuk bersaing dengan usaha dagang lainnya dan masyarakat luas mengenal produk songket khas UD. Undur Pasang.

Media informasi produk belum dimiliki oleh UD. Undur Pasang sehingga banyak masyarakat belum mengenal songket produk UD. Undur Pasang. Selama ini penjualan dilakukan secara langsung kepada konsumen atau sebaliknya konsumen yang telah menjadi pelanggan datang kembali ke UD. Undur Pasang. Oleh karena itu media informasi produk yang mudah namun tetap komunikatif menjadi solusi bagi UD. Undur Pasang dalam melakukan promosi. Penggunaan katalog akan mempermudah calon konsumen untuk mendapatkan informasi lengkap tentang songket produk UD. Undur Pasang. Berdasarkan analisis situasi maka pembuatan katalog sebagai media informasi produk diperlukan oleh UD. Undur Pasang sebagai salah satu faktor meningkatkan usaha songket. Dengan memiliki katalog, konsumen dapat memilih dan menentukan produk yang akan dibeli karena katalog dilengkapi dengan rincian produk yang dihasilkan oleh UD. Undur Pasang.

Penerbitan katalog menjadi bagian penting keberadaan usaha dagang dengan melihat model dan desain yang mengacu pada kecendrungan-kecendrungan pasar. Proses pengadaan katalog pada UD. Undur Pasang sepenuhnya dilakukan dengan diskusi/sharing terkait bentuk, letak dan komposisi desain untuk penerbitan katalog guna kemudahan dan efisiensi konsumen melihat produk. Katalog yang baik akan memicu minat konsumen untuk mengetahui lebih banyak keberadaan produk, sehingga proses diskusi dari pemilik, penenun, serta keberadaan produk, mulai dari proses pembuatan, proses detail, finishing, dan display produk didokumentasikan bertahap agar semua menjadi sumber data yang penting. Katalog akan dibuat dengan isian data produk melalui komunikasi yang baik untuk saran penyajian dalam bentuk dan model desain yang mengacu pada perkembangan saat ini.

\section{METODE}

Metode Pelaksanaan Pengabdian Kepada Masyarakat ini terdiri dari 3 (tiga) bagian yang terdiri dari persiapan, pelaksanaan dan evaluasi.

\section{Persiapan}

a. Observasi atau survey kepada sasaran Pengabdian Kepada Masyarakat

b. Sosialisasi:bertujuan untuk memberikan informasi kepada Mitra dan penenun Songket Lombok sebagai bentuk penguatan komitmen untuk mensukseskan kegiatan Program Pengabdian Kepada Masyarakat. Tim Pelaksana akan memberikan informasi tentang pentingnya media informasi produk berupa buku catalog untuk menunjang dan mengembangkan usaha songket Lombok UD. UndurPasang.

c. Persiapan kegiatan: bertujuan untuk mengidentifikasikan dan menyiapkan kebutuhan pelaksanaan kegiatan. Persiapan kegiatan dilaksanakan bersama-sama dengan Mitra 
dan kegiatannya terdiri dari: 1) ersiapan materi katalog, dan 2) Mekanisme pelaksanaan

\section{Pelaksanaan}

Pelaksanaan kegiatan dibagi menjadi tiga tahap: 1) Tahap pertama: Fokus pada pengumpulan materi yang berhubungan dengan Songket Lombok dan produk UD. Undur Pasang, 2) Tahap kedua: Diskusi tentang materi yang telah dikumpulkan yang melibatkan Mitra dan Tim Pelaksana Pengabdian Kepada Masyarakat, dan 3) Tahap ketiga: penyelesaian buku katalog

\section{Evaluasi}

Evaluasi terhadap pelaksanaan pembuatan katalog mulai dari persiapan sampai diselesaikannya buku katalog produk UD. Undur Pasang

\section{HASIL DAN PEMBAHASAN}

Pada awal kegiatan tim pelaksana kegiatan Pengabdian Kepada Masyarakat melaksanakan sosialisasi. Sosialisasi dilaksanakan agar para penenun dan karyawan UD. Undur Pasang mengetahui tujuan dilaksanakannya Pengabdian Kepada Masyarakat dan manfaat media promosi bagi UD. Undur Pasang.

Sosialisasi manfaat media promosi bagi usaha dagang ini juga bertujuan agar para penenun memiliki pemahaman tentang pentingnya media promosi melalui model sederhana seperti katalog yang akan memudahkan konsumen dalam melihat proses dan detail produk. Keberadaan katalog menjadi representasi produk, pemilik dan penenun dalam memaksimalkan hasil produksi sehingga minat konsumen melihat keseluruhan proses produk dapat ditampilkan melalui konsep/desain katalog.

Proses pembuatan katalog ditentukan dari hasil diskusi dengan sumber produk (pemilik dan penenun) dalam menentukan bentuk dan fungsi katalog sebagai bahan/media promosi yang baik. Katalog akan menjadi informasi menarik yang diinformasikan langsung oleh pemilik dengan kelebihan-kelebihan produknya, baik itu proses, kreatifitas produk, aksesori pendukung dan kelebihan-kelebihan lainnya. Melalui proses tersebut, pemahaman dibentuknya katalog sebagai media promosi akan sangat membantu semua aspek dalam menentukan arah pasar. Informasi yang diberikan pemilik dan para anggota sosialisasi akan memaksimalkan bentuk desain katalog dalam menentukan kecenderungan model dan bentuk katalog terhadap konsumen serta bagaimana membuat katalog yang baik dan efisien dalam menentukan minat konsumen.

Peran serta Mitra dalam perwujudan katalog selain dari informasi yang diberikan langsung oleh pemilik dan para penenun, informasi letak wilayah yang strategis menjadi pendukung keberadaan UD. Undur Pasang. Fasilitas jalan yang memadai akan memudahkan konsumen dalam visitasi mereka mengetahui informasi produk. Selain itu penataan letak/display karya menjadipenting untuk kenyamanan pengunjung dalam melihat karya serta informasi produk (katalog) di setiap penataan produk.

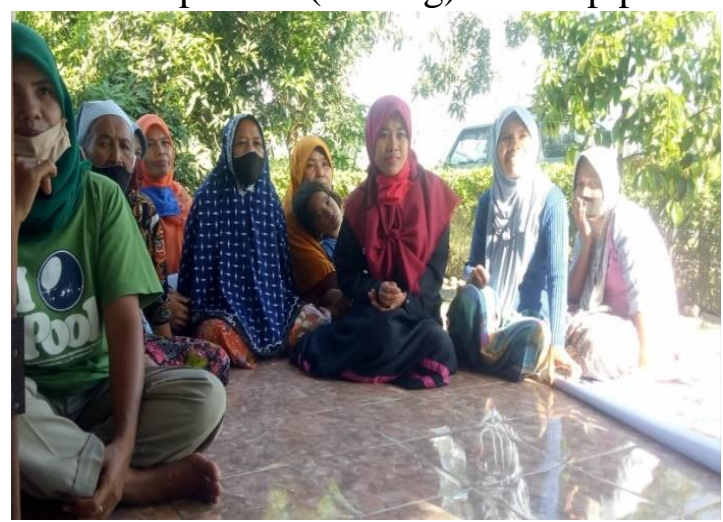

Gambar 1. Peserta Sosialisasi 
Setelah dilaksanakan sosialisasi, kegiatan berikutnya adalah mengumpulkan materi untuk dijadikan bahan katalog. Katalog yang akan dibuat berisi produk UD. Undur Pasang antara lain berbagai motif songket, sapuq dan produk-produk lainnya yang diproduksi dan dijual oleh UD. Undur Pasang. Motif-motif songket dan kain tenun lainnya yang akan ditampilkan dalam katalog terdiri dari Subahnale, Keker, Wayang, Kiping, Nanas, Kecubung, Pecuk Melung, Tapo Kemalo, Bulan Kurung, Bintang Empet, Bintang Remawe, Ragi genep, Selulut, Senangin, Rang Rang. Selain itu Sapuq dan Lambung yang merupakan pakaian adat Sasak bagi kaum perempuan juga tercantum pada katalog.

Upaya sosialisasi penerapan katalog diperlukan peran serta mitra dalam memberikan pemahaman pada setiap roduk. Baik itu pada nama-nama dan jenis motif yang berbeda. Satu contoh misalnya, penamaan jenis motif Subhanale. Pada 1 (satu) jenis motif tersebut memiliki kesamaan dengan kain yang akan selanjutnya dibuat dengan motif tersebut, tetapi pada proses selanjutnya motif tersebut dapat diterapkan pada warna yang berbeda dan ukuran kain yang berbeda pula. Informasi inilah yang dihimpun dalam perwujudan katalog, informasi tentang perkembangan dan keberadaan motif-motif yang diterapkan pada kain akan menjadi ilmu pengetahuan yang baik dalam mengetahui aspek histori dalam penggunaan kain sehingga konsumen bisa memilah mana yang cocok untuk penerapan pemakaiannya. Demikian pula dengan jenis dan nama motif seperti Keker, Wayang, Kecubung, dan sebagian besar nama dan jenis lainnya.

Melalui penerapan nama dan jenis motif pada setiap produk, upaya perwujudan katalog melalui informasi mitra akan memudahkan desain pada katalog yang memungkinkan semua informasi-informasi terkait dengan produk dapat dihimpun dalam katalog. Informasi yang dihimpun melalui diskusi pengambilan gambar dan diskusi/wawancara lainnya terkait dengan produksi setiap bentuk proses dan hasil menjadi kemudahan dalam menentukan tata letak dan desain katalog.

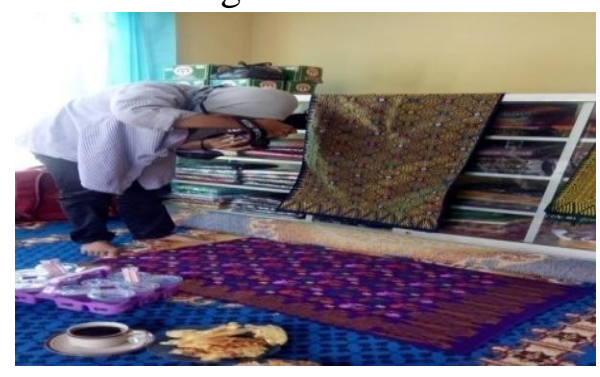

Gambar 2. Pengambilan Gambar untuk Katalog

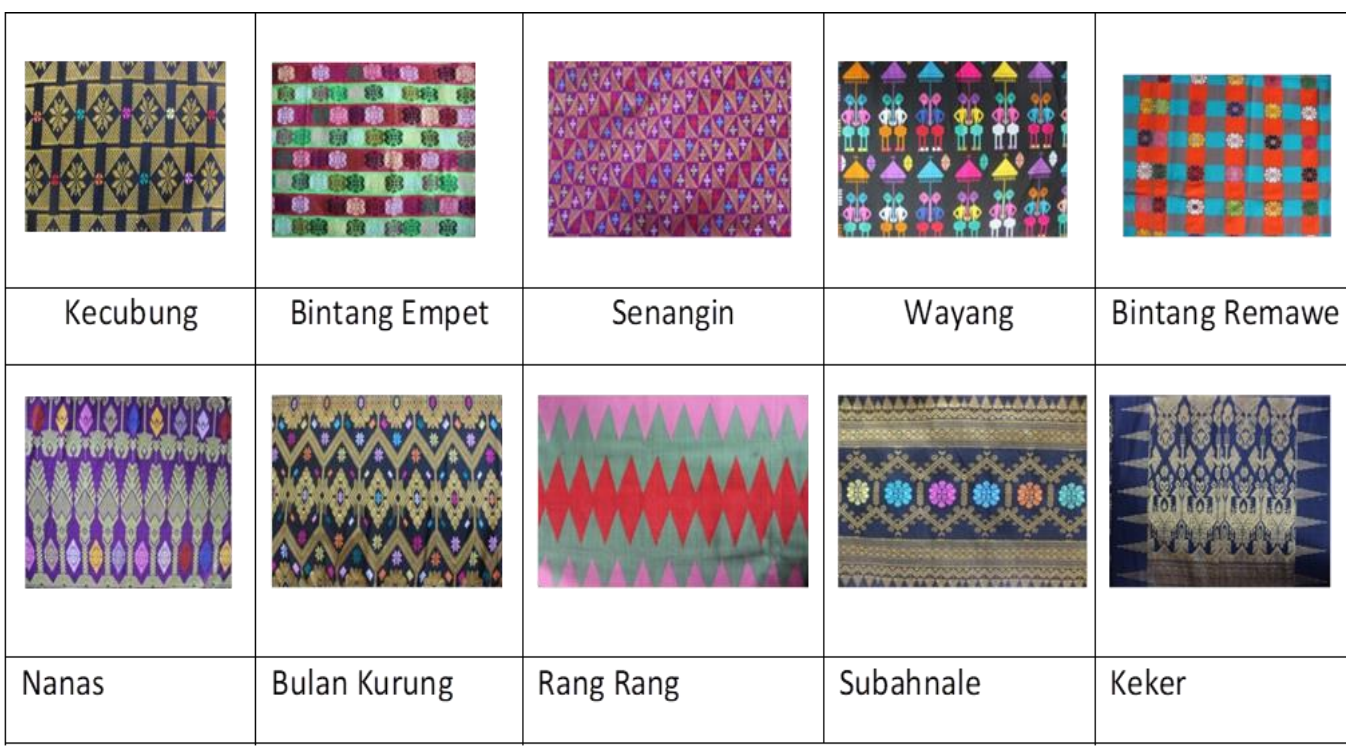

Gambar 3. Sebagian dari Isi Katalog 
Identifikasi ragam produk UD. Undur Pasang ini dilakukan untuk memilah-milah jenis produk yang akan ditampilkan di katalog. Ragam produk UD. Undur Pasang terdiri dari:

a. Songket

Ragam motif kain Songket produk UD. Undur Pasang terdiri dari Subahnale, Keker, Wayang, Kiping, Nanas, Kecubung, Bulan Kurung, Bintang Empet, Bintang Remawe, Senangin, Kembang Setaman

b. Kain tenun lainnya seperti Ragi Genep, Selulut, Pecuk Melung, Tapo Kemalo, Rang Rang

c. Aksesori: Sapuq (pelengkap pakaian adat laki-laki yang dikenakan di kepala), selendang, pakaian adat Lambung

Salah satu entitas dalam domain seni rupa adalah fotografi, maka dengan hal tersebut fotografi tidak terlepas dari nilai-nilai dan kaidah estetika seni rupa yang berlaku (Soedjono, 2006). Dengan berbagai jenisnya fotografi tidak terlepas dari varian nilai dan kosa estetikanya sendiri. Setiap kehadiran jenis fotografi tentunya juga memerlukan konsep perancangan yang berawal dari ide dasar yang berkembang menjadi implementasi praktis yang memerlukan dukungan peralatan dan teknik ungkap kreasinya.

Dalam praktek fotografi, tidak jarang jika setiap objek perlu difoto beberapa kali dengan berbagai sudut pandang/angle ataupun dengan varian lensa dengan filter khusus dan paduan pencahayaan. Semua itu digunakan dengan tujuan untuk mendapatkan berbagai hasil tampilan fotografi yang memiliki nilai estetika dan memberikan hasil foto terbaik yang sesuai dengan nilai estetika yang diharapkan.

Pembuatan media informasi produk berupa katalog dimulai dengan membuat konsep berdasarkan ragam produk UD. Undur Pasang. Untuk membuat media katalog lebih menarik diperlukan foto dari produk yang akan ditampilkan. Foto yang diambil mempertimbangkan sisi atau angle dari produk tersebut. Secara keseluruhan produk difoto dari beberapa sisi atau angle dan posisi secara diagonal sehingga dapat dilihat dengan jelas.

Setelah proses foto produk dilaksanakan, langkah selanjutnya adalah membuat katalog dengan membuat desain dan informasi produk yang akan ditampilkan dalam katalog tersebut. Berikut tampilan katalog.

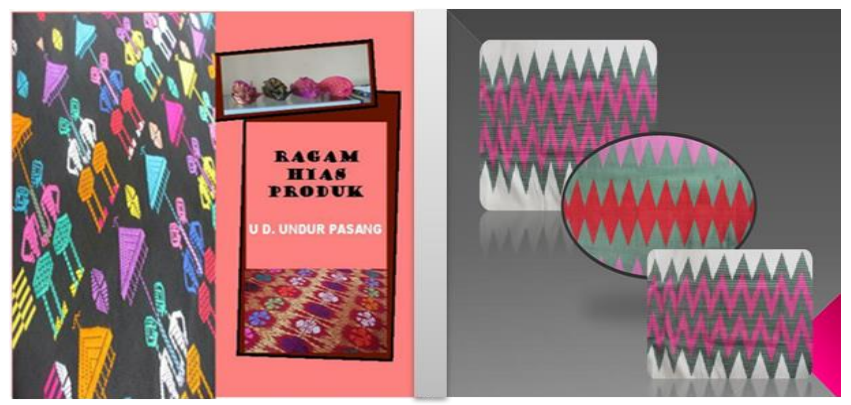

Gambar 5. Cover Depan dan Cover Belakang Katalog

\section{KESIMPULAN}

Penggunaan katalog sebagai media informasi produk dan promosi belum pernah dilakukan oleh UD. Undur Pasang. Hal ini berdampak pada pada omzet penjualan. Aktifitas promosi dan penjualan dilakukan secara door to door sehingga jangka waktu untuk memasarkan produk menjadi lebih lama. Solusi atas permasalahan ini adalah dengan membuat media informasi produk dalam bentuk katalog karena katalog merupakan media informasi yang mudah dipahami oleh konsumen.

Katalog yang dibuat berisi informasi tentang produk UD. Undur Pasang. Informasi produk tersebut terdiri dari songket, kain tenun selain songket dan aksesori yang diproduksi dan dijual oleh UD. Undur Pasang. Gambar produk dapat dilihat dengan jelas melalui foto yang ditampilkan dalam katalog dengan tampilan yang menarik. 


\section{SARAN}

Disarankan agar dilakukan pembaharuan pada katalog apabila ada produk baru yang diproduksi oleh UD. Undur Pasang. Diupayakan juga untuk membuat katalog online karena kemudahan untuk mengakses internet, memilih produk sampai pemesanan merupakan daya tarik tersendiri bagi konsumen.

\section{UCAPAN TERIMA KASIH}

Ucapan terimakasih disampaikan kepada Universitas Pendidikan Mandalika melalui LPPM Undikma yang telah memberikan dana kegiatan Pengabdian Kepada Masyarakat ini. Ucapan terimakasih juga disampaikan kepada penenun, staf dan manajer UD. Undur Pasang atas partisipasi dan kerjasamanya sehingga pelaksanaanPengabdian Kepada Masyarakat ini dapat dilaksanakan dengan baik.

\section{DAFTAR PUSTAKA}

Bungin, B. (2006). Sosiologi Komunikasi (p.39). Jakarta: Kencana

Cahyadi, F., \& Wijaya, P. S. M. (2011). Pengaruh Katalog Produk Terhadap Minat Beli Kembali Konsumen Carrefour Yogyakarta. Jurnal Riset Manajemen dan Bisnis, 6 (1), 55-67. Retrieved from http://e-journalfb.ukdw.ac.id/index.php/jrmb/article/view/72/53

Hasanah, K. (2015). Promosi Katalog Harga dan Keputusan Pembelian di Indomaret, Studi Kasus Pada Konsumen Indomaret Kota Madiun. JIBEKA, 9 (1) 65-69. Retrieved from http://pics.unipma.ac.id/content/download/B009_15_06_2020_03_46_472_JIBEKA\%2 0Vol\%209\%20No\%201_2015_compressed.pdf

Kotler, P., \& Gary A. (2014). Principle Of Marketing, $15^{\text {th }}$ edition (p.408). New Jersey: Pearson Prentice Hall

Kusrianto, A. (2007). Pengantar Desain Komunikasi Visual (p.331). Yogyakarta: Andi Offset Mulyana, D. (2005). Ilmu Komunikasi Suatu Pengantar (p.63). Bandung: PT. Remaja Rosdakarya

Praswati, A N., Syamsudin, Isa M., \& Prijanto T. (2016). Strategi Pemasaran Katalog Produk (Studi Kasus Pengrajin Bambu Sukodono Sragen). BENEFIT Jurnal Manajemen dan Bisnis. 1 (2) 149-155. Retrieved from : https://doi.org/10.23917/benefit.v1i2.3258

Putra, U. D. S. (2019). Perancangan Katalog Wisata Kota Surabaya Sebagai Media Informasi Massa. Jurnal GESTALT. 1 (1). 95-102. Retrieved from https://media.neliti.com/media/publications/301541-perancangan-katalog-wisata-kotasurabaya-4d50cf50.pdf

Rompis, D., Tumbuan, W., \& Sumarauw, J. (2017). Pengaruh Bauran Pemasaran Terhadap Volume Penjualan Pada PT. Tridjaya Mulia Sukses. ISSN:2303-1174. Jurnal Emba 5(3).3078-3087. Retrieved from https://ejournal.unsrat.ac.id/index.php/emba/issue/view/1861

Ruben, B. D., \& Stewart, L. P. (2013). Komunikasi dan Perilaku Manusia. Jakarta: Rajawali Press

Soedjono, S. (2006). Pot-Pourri Fotografi (p.7). Jakarta: Universitas Trisakti 